\title{
PENYULUHAN DAN PELATIHAN GURU IPA SMP MUHAMMADIYAH SE-KOTA YOGYAKARTA TERKAIT SOAL-SOAL UJIAN NASIONAL BERBASIS HIGH ORDER THINKING SKILL (HOTS)
}

\author{
Oleh: \\ M. Joko Susilo, Etika Dyah Puspitasari, Purwanti Pratiwi Purbosari \\ Universitas Ahmad Dahlan \\ E-mail: jokoms_uad@yahoo.com
}

\section{Ringkasan}

Guru merupakan mata tombak utama pendidikan nasional karena guru merupakan pihak yang langsung berhadapan dan berinteraksi dengan siswa. Guru berpengaruh besar terhadap kualitas proses pembelajaran dan hasil pembelajaran di sekolah. Oleh karena itu, peningkatan kompetensi guru menjadi hal yang penting dalam usaha memajukan pendidikan di Indonesia. Salah satu langkah yang dapat dilakukan pihak perguruan tinggi, khususnya bagi para dosen, untuk turut meningkatkan kompetensi guru adalah dengan memberikan pendalaman materi dan pembimbingan penyusunan butir soal Ujian Nasional. Berdasarkan nilai hasil Ujian Nasional 2016 diketahui bahwa untuk beberapa indikator SKL yang diujikan, rata-rata siswa SMP kota Yogyakarta mendapatkan nilai rendah. Oleh karena itu, dirasa perlu untuk memberikan pendalaman materi pada topik-topik tertentu bagi para guru, sekaligus meningkatkan pemahaman guru terhadap soal-soal berbasis High Order Thinking Skill (HOTs) yang memiliki porsi tersendiri dalam soal Ujian Nasional tingkat SMP.

Metode yang digunakan dalam kegiatan ini adalah berupa penyuluhan dan pelatihan. Penyuluhan yang dilakukan yaitu terkait bedah SKL IPA Biologi dan pendalaman materi. Sedangkan pelatihan yang dilakukan difokuskan pada pelatihan penyusunan butir soal Ujian Nasional IPA SMP berbasis HOTs.

Setelah melakukan bedah SKL sekaligus melihat data hasil Ujian Nasional 2016 didapatkan fakta bahwa rata-rata siswa SMP di Kota Yogyakarta mendapatkan nilai yang rendah untuk topik materi fotosintesis dan bagian-bagian mikroskop. Dengan demikian dilakukan pendalaman materi untuk kedua topik tersebut. Selanjutnya berdasarkan analisis terhadap indikator SKL diketahui terdapat 4 materi pokok yang memungkinkan keluar sebagai soal berbasis HOTs pada Ujian Nasional 2017. Keempat materi pokok tersebut meliputi materi ekosistem, kepadatan populasi, pencemaran lingkungan dan fotosintesis. Oleh karena itu, selanjutnya dilakukan pembimbingan penyusunan soal Ujian Nasional berbasis HOTs untuk keempat materi pokok tersebut. Dari hasil pembimbingan tersebut dihasilkan 20 butir soal prediksi Ujian Nasional berbasis HOTs.

Dari kegiatan yang telah dilaksanakan dapat disimpulkan bahwa terdapat beberapa topik materi dimana rata-rata siswa SMP kota Yogyakarta mendapatkan nilai rendah saat Ujian Nasional sehingga dilakukan pendalaman materi untuk para guru IPA SMP Muhammadiyah se-Kota Yogyakarta. Selain itu, terdapat empat topik materi yang memungkinkan akan disajikan dalam bentuk soal berbasis HOTs pada Ujian Nasional sehingga dilakukan penyusunan butir soal berbasis HOTs untuk keempat topik materi tersebut.

Kata kunci: Penyuluhan, Pelatihan, Guru IPA SMP Muhammadiyah, Soal Ujian Nasional, Hots.

\section{Abstract}

Teachers are the main spearhead of national education because the teacher is a party that directly confronts and interacts with students. Teachers have a big effect on the quality of learning process and learning outcomes in school. Therefore, the improvement of teacher competence becomes an important thing in the effort to 
improve education in Indonesia. One of the steps that can be done by universities, especially for lecturers, to contribute to improve teachers' competence is by providing material deepening and guidance on the preparation of items on National Examination. Based on the results of the National Examination 2016 note that for some indicators SKL tested, the average junior high school students of Yogyakarta get a low score. Therefore, it is necessary to provide material deepening on certain topics for teachers, as well as to improve teachers' understanding of High Order Thinking Skill (HOTs) -based issues that have their own portion in the junior high school

exam.

The method used in this activity is in the form of counseling and training. Counseling that is done related to SKL IPA Biology and deepening of the material. While the training is focused on the preparation of training on the subject of National Exam IPA SMP based HOTs. After doing SKL surgery at the same time looking at the data of National Examination result 2016 got the fact that average junior high school student in Yogyakarta get low score for topic of photosynthesis material and parts of microscope. Thus the deepening of the material for both topics. Furthermore, based on the analysis of the SKL indicator, it is known that there are 4 main subjects that allow out as a HOTs-based problem in the National Examination 2017. The four main materials include ecosystem material, population density, environmental pollution and photosynthesis. Therefore, the guidance is then made of the preparation of the question of National Examination based on HOTs for the four basic materials. From the results of the guidance is generated 20 items about the prediction of National Examination based on HOTs. From the activities that have been carried out can be concluded that there are some material topics where the average junior high school students of Yogyakarta get a low score during the National Examination so that the material is deepening for the teachers of science SMP Muhammadiyah all over Yogyakarta. In addition, there are four possible material topics that will be presented in the form of HOTs-based questions on the National Examination so that HOTs-based items are prepared for the four material topics. Keywords: Counseling, Training, Science Teacher SMP Muhammadiyah, National Examination Problem, Hots

\section{A. PENDAHULUAN}

Guru merupakan mata tombak utama pendidikan nasional karena guru merupakan pihak yang langsung berhadapan dan berinteraksi dengan siswa. Guru berpengaruh besar terhadap kualitas proses pembelajaran dan hasil pembelajaran di sekolah. Oleh karena itu, peningkatan kompetensi guru menjadi hal yang penting dalam usaha memajukan pendidikan di Indonesia. Dalam hal ini pemerintah juga menetapkan adanya standar kualifikasi dan standar kompetensi bagi guru agar dapat termonitor secara pasti kualitas guru yang mengajar di sekolah, baik pada jenjang PAUD/TK/RA, SD/MI, SMP/MTs, SMA/MA dan SMK/MAK. Muhibin (2011:229) memberikan rumusan bahwa kompetensi guru merupakan kemampuan dan kewenangan guru dalam melaksanakan profesinya, sedangkan profesionalisme berarti kualitas dan perilaku khusus yang menjadi ciri khas guru yang profesional. 
Salah satu langkah yang dapat dilakukan pihak perguruan tinggi, khususnya bagi para dosen, untuk turut meningkatkan kompetensi guru adalah dengan memberikan pendalaman materi dan pembimbingan penyusunan butir soal Ujian Nasional. Berdasarkan nilai hasil Ujian Nasional 2016 diketahui bahwa rata-rata siswa SMP kota Yogyakarta mendapatkan nilai rendah untuk beberapa indikator SKL tertentu (Kemendikbud 2016). Oleh karena itu dirasa perlu untuk memberikan pendalaman materi pada topik-topik tertentu bagi para guru, sekaligus meningkatkan pemahaman guru terhadap soal-soal berbasis High Order Thinking Skill (HOTs) yang memiliki porsi tersendiri dalam soal Ujian Nasional tingkat SMP. Pemahaman guru yang lebih mendalam dan komprehensif menjadi modal utama dalam membelajarkan siswa dan sangat berpengaruh pula terhadap pemahaman siswa. Dengan demikian diharapkan nantinya akan terjadi kenaikan nilai siswa pada Ujian Nasional di tahun berikutnya. Selain itu, pada soal-soal Ujian Nasional terdapat pula beberapa soal yang menekankan prinsip berfikir tingkat tinggi. Soal-soal ini sudah mengarah pada tingkat berfikir analisis, evaluasi dan mencipta. Jenis soal seperti ini biasa disebut pula sebagai soal-soal berbasis High Order Thinking Skill (HOTs). Adanya pemahaman guru terhadap soal-soal berbasis HOTs juga menjadi hal yang penting untuk mempersiapkan siswa menghadapi Ujian Nasional.

Dengan melihat berbagai hal di atas maka tim dosen Prodi Pendidikan Biologi mencoba melakukan kegiatan penyuluhan dan pelatihan guru-guru IPA SMP Muhammadiyah se-Kota Yogyakarta terkait soal-soal Ujian Nasional berbasis HOTs. Kegiatan ini bertujuan untuk memberikan pendalaman materi bagi guru-guru SMP Muhammadiyah se-Kota Yogyakarta, sekaligus memberikan pelatihan penyusunan soal Ujian Nasional berbasis HOTs.

\section{B. METODE PELAKSANAAN}

Metode dalam pelaksanaan kegiatan ini meliputi penuluhan dan pelatihan. Penyuluhan dilakukan saat pendalaman materi untuk beberapa topik yang dirasa perlu diberikan kepada guru -guru SMP Muhammadiyah se-Kota Yogyakarta. Sedangkan kegiatan pelatihan difokuskan dalam penyusunan soal-soal Ujian Nasional berbasis HOTs.

\section{HASIL, PEMBAHASAN DAN DAMPAK}

Kegiatan pengabdian ini dilaksanakan melalui kerja sama dengan PDM Kota Yogyakarta, khususnya Majelis Pendidikan Dasar dan Menengah. Sedangkan sasaran peserta kegiatan adalah guru-guru IPA SMP Muhammadiyah se-Kota Yogyakarta.

Acara dibagi menjadi beberapa kali pertemuan. Pada pertemuan pertama, tim dosen mencoba untuk mengidentifikasi kesulitan proses pembelajaran dan penilaian IPA Biologi SMP dengan guru-guru IPA SMP Muhammadiyah se-Kota Yogyakarta. Kegiatan ini dilaksanakan pada tanggal 21 Januari 2017. Beberapa kesulitan yang dirasakan oleh guru di lapangan adalah rata-rata mereka belum memahami cara pembuatan soal yang berkualitas dan representatif. Selain itu, hampir sebagian besar guru IPA di sekolah-sekolah Muhammadiyah Kota Yogyakarta bukansarjana yang berasal dari jurusan Pendidikan IPA, melainkan sarjana Pendidikan Biologi, Pendidikan Fisika, atau bahkan sarjana ilmu murni. Selanjutnya pada tanggal 22 Februari 2017 dilakukan kegiatan bedah SKL sekaligus menetapkan materi-materi apa saja yang akan digunakan untuk materi pendalaman. 
Setelah disepakati materinya, kemudian pada tanggal 25 Februari 2017 dilakukan pendalaman untuk materi pokok pertumbuhan dan perkembangan tumbuhan. Sedangkan pada tanggal 4 Maret 2017 dilakukan pendalaman untuk materi pokok bagian-bagian mikroskop.

Pada tanggal 13 Maret 2017 dilakukan pendampingan pengembangan penyusunan butir soal IPA SMP, khususnya materi Biologi. Kegiatan ini dilanjutkan pada tanggal 22 April 2017 untuk penyusunan soal Ujian Nasional berbasis HOTs. Menurut Anderson \& Krathwohl domain proses kognitif yang termasuk dalam kemampuan berfikir tingkat tinggi (High Order Thinking Skill/HOTs) adalah domain analisis (analyze), evaluasi (evaluate) dan mencipta (create) (Edi Istiyono, 2014). Jika dilihat dalam revisi taksonomi Bloom terbaru maka domain tersebut merupakan tingkat C4, C5 dan C6 ( Imam \& Anggarini, 2016). Oleh karena itu, berdasarkan analisis terhadap indikator SKL didapatkan 4 materi pokok yang memungkinkan untuk dibuat sebagai soal berbasis HOTs pada Ujian Nasional. Data tersebut disajikan pada Tabel 1.

Tabel 1. Hasil Analisis Indikator SKL yang Mengarah pada Soal Ujian Nasional Berbasi HOTs

\begin{tabular}{|c|l|l|}
\hline No & \multicolumn{1}{|c|}{ Indikator SKL } & Materi \\
\hline 28 & $\begin{array}{l}\text { Disajikan jaring-jaring makanan pada suatu } \\
\text { ekosistem, peserta didik dapat memprediksi } \\
\text { akibat salah satu komponennya mengalami } \\
\text { gangguan/turun populasinya }\end{array}$ & Ekosistem \\
\hline 29 & $\begin{array}{l}\text { Disajikan grafik tentang kepadatan populasi } \\
\text { manusia, peserta didik dapat menyebutkan } \\
\text { akibatnya terhadap lingkungan }\end{array}$ & Kepadatan Populasi \\
\hline 30 & $\begin{array}{l}\text { Disajikan kasus pencemaran, peserta didik } \\
\text { dapat memberi contoh mengatasi dampak } \\
\text { pencemaran }\end{array}$ & Pencemaran Lingkungan \\
\hline 38 & $\begin{array}{l}\text { Disajikan gambar percobaan fotosintesis, } \\
\text { peserta didik dapat menginterpretasikan } \\
\text { hasilnya }\end{array}$ & Fotosintesis \\
\hline
\end{tabular}

Dari keempat materi pokok tersebut selanjutnya dituangkan menjadi soal-soal berbasis HOTs. Kumpulan soal yang telah dibuat selanjutnya diramu menjadi sebuah buku sebagai produk luaran dari kegiatan pengabdian kepada masyarakat ini. Buku yang dihasilkan diberi judul "Kumpulan Soal Ujian Nasional IPA Biologi SMP Berbasis High Order Thinking Skill (HOTs)". 
Diterbitkan oleh Lembaga Pengabdian kepada Masyarakat

Universitas Ahmad Dahlan Yogyakarta

\section{KESIMPULAN}

Kesimpulan yang dapat diperoleh dari kegiatan pengabdian ini adalah:

1. Kegiatan penyuluhan terhadap guru-guru IPA SMP Muhammadiyah se-Kota Yogyakarta dilakukan dengan memberikan pendalaman materi topik pertumbuhan dan perkembangan tumbuhan, serta bagian-bagian mikroskop.

2. Kegiatan pelatihan terhadap guru-guru IPA SMP Muhammadiyah se-Kota Yogyakarta difokuskan pada penyusunan soal-soal Ujian Nasional berbasis HOTs dan dari hasil pelatihan tersebut telah dihasilkan sebanyak 20 butir soal berbasis HOTs.

\section{DAFTAR PUSTAKA}

Imam Gunawan \& Anggarini Retno P., 2016. Taksonomi Bloom-Revisi Ranah Kognitif: Kerangka Landasan untuk Pembelajaran, Pengajaran dan Penilaian. E-journal IKIP PGRI Madiun.

Edi Istiyono, Djemari Mardapi, Suparno. 2014. Pengembangan Tes Kemampuan Berpikir Tingkat Tinggi Fisika (PysTHOTS) Peserta Didik SMA. Jurnal Penelitian dan Evaluasi Pendidikan: Th 18, No.1. 
